IRA-International Journal of Management \& Social Sciences

ISSN 2455-2267; Vol.05, Issue 01 (2016)

Pg. no. 187-193

Institute of Research Advances

http://research-advances.org/index.php/RAJMSS

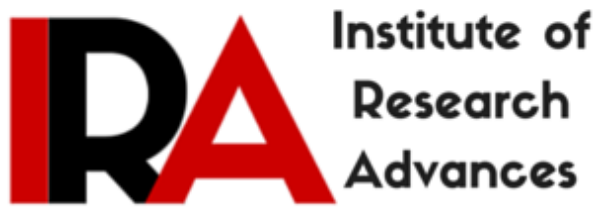

\title{
Self-Help Group of Rural Assam and Its Role in Women Empowerment
}

\author{
Dr. Polee Saikia ${ }^{1}$ \\ ${ }^{1}$ Associate Professor, Department of Education, \\ Gauhati University, Assam, India.
}

Type of Review: Peer Reviewed.

DOI: http://dx.doi.org/10.21013/jmss.v5.n1.p18

\section{How to cite this paper:}

Saikia, P. (2016). Self-Help Group of Rural Assam and Its Role in Women Empowerment. IRA-International Journal of Management \& Social Sciences (ISSN 2455-2267), 5(1), 187-193. doi:http://dx.doi.org/10.21013/jmss.v5.n1.p18

(C) Institute of Research Advances

\section{(c)) EY-NC}

This work is licensed under a Creative Commons Attribution-Non Commercial 4.0 International License subject to proper citation to the publication source of the work.

Disclaimer: The scholarly papers as reviewed and published by the Institute of Research Advances (IRA) are the views and opinions of their respective authors and are not the views or opinions of the IRA. The IRA disclaims of any harm or loss caused due to the published content to any party. 


\section{ABSTRACT}

Women empowerment is a universal issue. Women empowerment refers to the creation of an environment for women where they can make decisions of their own for their personal benefits as well as for the society. It refers to increasing and improving the social, economic, political and legal strength of the women, to ensure equal right to women and to make them confident enough to claim their rights. The overall development of the nation remains as a paradox until and unless the women got empowered. The under privileged rural women are still far from empowerment. Unemployment, illiteracy and low social recognition made them so. Presently the self-help groups that mushrooming in different corners of rural Assam have been creating opportunities for women to be empowered. Here in this study an attempt has been made to study whether the rural women got scope to get empowered by getting engagement in selfhelp groups. 40 women from 04 self-help groups, 13 literate and 27 illiterate women were taken as sample for the study. To collect first hand data self structured questionnaire and self structured interview schedule were prepared by the investigators. Percentage was used to analyze data.

KEY WORDS: Empowerment, self-help group, Kamrup (R).

\section{INTRODUCTION:}

The position of the women in the society is one of the most important issues which draws the attention of the people all over the world. India, as one of the third world countries has many good examples of the unequal distribution of right between man and woman. Although the constitution of India provides equal rights to all, in practical life, we see a reverse situation. Indian women are still undergoing the exploitation of the male dominated society which is a major drawback of the development of the society.

Women, especially in India are thought to be weaker than men, both physically and mentally. Things do not remain the same always. Women are now not the same as they were before. They are now enjoying equal freedom with the men. There is hardly any field in which women are not found now. This is a result of education in one hand and of the changing horizon on the perception of the women as well as man. Modern educated women are now free to get married according to their own choice. We find women occupying some important positions in the society now which is also regarded as women are now empowered.

Women empowerment is a universal issue. Women empowerment refers to the creation of an environment for women where they can make decisions of their own for their personal benefits as well as for the society. It refers to increasing and improving the social, economic, political and legal strength of the women, to ensure equal right to women and to make them confident enough to claim their rights, such as...

1. Living life freely with a sense of self-worth, respect and dignity.

2. Have complete control of their life, both within and outside of their home and workplace.

3. To make their own choices and decisions.

4. Have equal rights to participate in social, religious and public activities.

5. Have equal social status in the society.

6. Get equal opportunity for education.

7. Get equal employment opportunity without any gender bias 
8. Get safe and comfortable working environment.

\section{IMPORTANCE OF WOMEN EMPOWERMENT}

Women empowerment is important for the following reasons-

i. To solve women unemployment and under-employment

ii. Equal competence and intelligence

iii. Overall development of the society

iv. Economic benefit

$\mathrm{v}$. Reduction in domestic violence

vi. Reduction in corruption

vii. To reduce poverty and for

viii. National development.

\section{OBJECTIVE:}

To study whether the women got empowered by self-help group they engaged.

METHODOLOGY:

Descriptive survey method was applied in the present study by the investigator.

\section{SAMPLE:}

The investigator collected primary data randomly from 04 sample group (self-help) of Rampur Development Block under Palasbari Revenue Circle of Kamrup District of Assam through Purposive Sampling technique. 10 samples were taken from each group i.e. a total of 40 samples had been taken for the study. The sample comprises of 13 literate and 27 illiterate women working in weaving and knitting centre.

\section{TOOLS USED:}

(i). A self structured questionnaire (having Yes\No responses) was prepared for the literate samples in order to study women empowerment.

(ii). A self structured interview schedule (having Yes $\backslash$ No responses) was prepared for the illiterate samples in order to study women empowerment.

\section{STATISTICAL TECHNIQUE:}

Simple percentage was used in the present study to analyze data.

\section{DELIMITATION OF THE STUDY:}

(i). The study has taken into account only the rural Kamrup district of Assam.

(ii). The study has taken only the Rampur block out of the total blocks. 
(iii). The study has taken only the women (married \& unmarried) members.

(iv). The study has taken only four self-help groups of Rampur block.

\section{ANALYSIS OF THE STUDY:}

\section{OBJECTIVE:}

To study whether the women got empowered by self-help group they engaged.

In order to analyze the objective (women empowerment of the weaving and knitting groups) the investigator considered the following areas to be studied.

i). Income

ii). Family decision and decision for self

iii). Social position and recognition

iv). Education and

v). Domestic violence.

Depending upon the above areas the investigator studied the sub-areas in table-1 which indicate women empowerment and their responses have been given in percentages.

Table-1:Showing sub-areas on women empowerment in percentage

\begin{tabular}{|l|l|l|}
\hline \multicolumn{1}{|c|}{ Sub-areas on women empowerment } & "Yes" responses & "No" responses \\
\hline Income raised due to engagement in self-help group & $24(60 \%)$ & $16(40 \%)$ \\
\hline Bearing family expenses & $38(95 \%)$ & $02(5 \%)$ \\
\hline Saving regularly for the family & $15(37.5 \%)$ & $25(62.5 \%)$ \\
\hline Participation in family decisions & $31(77.5 \%)$ & $09(22.5 \%)$ \\
\hline $\begin{array}{l}\text { Decision for self like decisions on marriage, decision } \\
\text { about study }\end{array}$ & $26(65 \%)$ & $14(35 \%)$ \\
\hline Involvement in the neighborhood and society & $14(35 \%)$ & $26(65 \%)$ \\
\hline Helping social institutions by means of cash or kind & $16(40 \%)$ & $24(60 \%)$ \\
\hline Compulsion to earn for family & $23(57.5 \%)$ & $17(42.5 \%)$ \\
\hline Victimized by domestic violence & $10(25 \%)$ & $30(75 \%)$ \\
\hline Family permission for working outside & $29(72.5 \%)$ & $11(27.5 \%)$ \\
\hline
\end{tabular}

Out of the total 40 samples 13 have been found literate and the rests illiterate. The literates have been found up to vii passed only. Table 1 reveals that out of the total sample a $60 \%$ put positive response that their income level has been raised by the engagement in the self-help group. A 95\% believes that they bear family expenses as their male counter parts. Regarding regular savings out of their income only $37.5 \%$ responded positive. A $77.5 \%$ women take part in family decisions. A $65 \%$ women take their own decisions. These women have full freedom in taking their own decisions like marriage, receiving 
education and going out on trip. Involvement in the society and neighborhood by the women of the groups has been found only $35 \%$ which could be regarded insignificant involvement. A $60 \%$ women have been found not put forward any help to social institutions. 57.5\% women have been found compelled to work in the present job. Their financial contribution to the family is indispensible. A $75 \%$ women have reported that they have not been victimized by domestic violence against $25 \%$ such victims. The guardian of $72.5 \%$ women are agreed their wives working outside.

Table-2 indicates about the responses put forward by the literate and the illiterate samples regarding empowerment by engagement in work.

Table-2 showing responses by literate and illiterate women regarding empowerment in percentage

\begin{tabular}{|c|c|c|c|c|}
\hline \multirow{3}{*}{$\begin{array}{l}\begin{array}{l}\text { Sub-areas counted on women } \\
\text { empowerment }\end{array} \\
\begin{array}{l}\text { Income raised due to engagement in self-help } \\
\text { group }\end{array}\end{array}$} & \multicolumn{2}{|c|}{ (Literate sample) } & \multicolumn{2}{|c|}{ (Illiterate sample) } \\
\hline & Yes & No & Yes & No \\
\hline & $\begin{array}{l}06 \\
(46.15 \%)\end{array}$ & $\begin{array}{c}07 \\
(53.85 \%)\end{array}$ & $\begin{array}{l}18 \\
(66.67 \%)\end{array}$ & $\begin{array}{c}09 \\
(33.33)\end{array}$ \\
\hline Bearing family expenses & $\begin{array}{l}11 \\
(84.62 \%)\end{array}$ & $\begin{array}{c}02 \\
(15.38)\end{array}$ & $\begin{array}{l}27 \\
(100 \%)\end{array}$ & 00 \\
\hline Saving regularly for the family & $\begin{array}{l}05 \\
(38.46 \%)\end{array}$ & $\begin{array}{c}08 \\
(61.54 \%)\end{array}$ & $\begin{array}{l}10 \\
(37.04 \%)\end{array}$ & $\begin{array}{c}17 \\
(62.96 \%)\end{array}$ \\
\hline Participation in family decisions & $\begin{array}{l}12 \\
(92.31 \%)\end{array}$ & $\begin{array}{c}01 \\
(7.69 \%)\end{array}$ & $\begin{array}{l}19 \\
(70.37 \%)\end{array}$ & $\begin{array}{c}08 \\
(29.63 \%)\end{array}$ \\
\hline $\begin{array}{l}\text { Decision for self like decisions on marriage, } \\
\text { decision about study }\end{array}$ & $\begin{array}{l}11 \\
(84.62 \%)\end{array}$ & $\begin{array}{c}02 \\
(15.38 \%)\end{array}$ & $\begin{array}{l}15 \\
(55.56 \%)\end{array}$ & $\begin{array}{c}12 \\
(44.44 \%)\end{array}$ \\
\hline Involvement in the neighborhood and society & $\begin{array}{l}08 \\
(61.54 \%)\end{array}$ & $\begin{array}{c}05 \\
(38.46 \%)\end{array}$ & $\begin{array}{l}06 \\
(22.22)\end{array}$ & $\begin{array}{c}21 \\
(77.78)\end{array}$ \\
\hline $\begin{array}{l}\text { Helping social institutions by means of cash or } \\
\text { kind }\end{array}$ & $\begin{array}{l}06 \\
(46.15 \%)\end{array}$ & $\begin{array}{c}07 \\
(53.85 \%)\end{array}$ & $\begin{array}{l}10 \\
(37.04 \%)\end{array}$ & $\begin{array}{c}17 \\
(62.96)\end{array}$ \\
\hline Compulsion to earn for family & $\begin{array}{l}04 \\
(30.77 \%)\end{array}$ & $\begin{array}{c}09 \\
(69.23 \%)\end{array}$ & $\begin{array}{l}19 \\
(70.37 \%)\end{array}$ & $\begin{array}{c}08 \\
(29.63 \%)\end{array}$ \\
\hline Victimized by domestic violence & $\begin{array}{l}03 \\
(23.08 \%)\end{array}$ & $\begin{array}{c}10 \\
(76.92 \%)\end{array}$ & $\begin{array}{l}07 \\
(25.93 \%)\end{array}$ & $\begin{array}{c}20 \\
(74.07 \%)\end{array}$ \\
\hline Family permission for working outside & $\begin{array}{l}10 \\
(76.92 \%)\end{array}$ & $\begin{array}{c}03 \\
(23.08 \%)\end{array}$ & $\begin{array}{l}19 \\
(70.37 \%)\end{array}$ & $\begin{array}{c}08 \\
(29.63 \%)\end{array}$ \\
\hline
\end{tabular}

Out of the total 40 samples 13 have been found literate and 27 illiterate. The literates have been found up to vii passed only. Table 2 reveals the responses of the literate sample and the illiterate sample about their empowerment in different areas of women empowerment separately. Out of the total 27 sample, $66.67 \%$ illiterate women reported that their income level has increased only after their engagement in the new line of work. While out of the total 13 literate sample only $46.15 \%$ women responded so. $100 \%$ illiterate women believe that they bear family expenses as their male counter parts against $84.62 \%$ literate women. 
Regarding regular savings out of their income only $37.4 \%$ illiterate women and $38.46 \%$ literate women responded positive. A $92.31 \%$ literate woman takes part in family decisions against $70.37 \%$ illiterate women. Among the literate sample self decision has been found more significant than their illiterate counterparts. A $84.62 \%$ literate women take their own decisions while $55.56 \%$ illiterate women takes their own decisions. These women have full freedom in taking their own decisions like marriage, receiving education and going out on trip. Involvement in the society and neighborhood activities by the women of the groups has been found only $22.22 \%$ among illiterate and $61.54 \%$ among literate women. $60 \%$ women have been found not put forward any help to social institutions. 57.5\% women have been found compelled to work in the present job. Their financial contribution to the family is indispensible. A $75 \%$ women have reported that they have not been victimized by domestic violence against $25 \%$ such victims. In this area no difference has been found between literate and illiterate sample i.e. $23.08 \%$ is found to be victimized among the literates against $25.93 \%$ illiterate victims. Again $76.92 \%$ has been found not victimized among the literates against $74.07 \%$ illiterate non victims. The guardian of $72.5 \%$ women are agreed their wives working outside. Out of the total 13 literate sample, $76.92 \%$ women enjoy freedom in working outside while out of 27 illiterate sample 70.37 enjoy freedom in working outside.

\section{FINDINGS OF THE STUDY:}

1. Among the illiterate women, empowerment has been found more severe. A $66.67 \%$ illiterate women have been found raised their income level by their engagement in the group.

2. Out of the total sample $95 \%$ has been found bear family expenses against $100 \%$ illiterate women. Regarding family expenditure $100 \%$ illiterate women have been found bear family expenses.

3. Regarding family decisions, literate women have been found participated highly. $92.13 \%$.

4. Women empowerment has also been experienced in regard of taking their own decisions. A $65 \%$ women have been found take their own decisions.

5. Participation in social activities by these women have been found very poor. Only $35 \%$ women have social and neighborhood involvement. They have been found yet to empowered in this regard.

6. Women empowerment has been experienced in regard of domestic violence. A $75 \%$ women have reported not victimized by domestic violence.

7. $72.5 \%$ women of the self-help groups have been found enjoying full freedom in regard of their working outside home.

\section{CONCLUSION:}

Though India has been on the path of development Indian women are still undergoing the exploitation of the male dominated society which is a major drawback of the development of the society.

Women, especially in India are thought to be weaker than men, both physically and mentally. Things do not remain the same always. Women are now not the same as they were before. They are now enjoying equal freedom with the men. There is hardly any field in which women are not found now. This is a result of education in one hand and of the changing horizon on the perception of the women as well as man. Modern educated women are now free to get married according to their own choice. We find women occupying some important positions in the society now which is also regarded as women are now empowered. Women are now found to be engaged in educational institution, bank, companies, space, medical science, engineering, household and even in petty trades. Women earn as much as their male counterparts earn, women take their own decisions as well as family decisions, women get involved in 
social activities and forward help to social institutions, women are now not get victimized by domestic violence, women are now educated and they even go outside to work. Thus they empowered themselves.

\section{REFERENCES :}

Agarwal, J. C. (1999). Education in emerging India.Vikash Publishing House Pvt. Ltd., Jangpura, New Delhi.

Ahmed, Jaynal U. (2010). Development Vision Of North-East India. 1stEdition. Concept Publishing Company (p) Ltd, New Delhi.

Ahuja, R. (2011). Research Methods.Rawat Publications, Jawahar Nagar,Jaipur.

Ahuja, R. (1999). Social Problems in India.Rawat Publications, JawaharNagar, Jaipur.

Ali Ahmed, K. (2007). Status of Women in India. EBH Publishers,Guwahati-1.

Arunachalam, J. and Kalpagam, U. (2007).Rural Women in South Asia.

Rawat Publications, Jawahar Nagar, Jaipur.

Bagchi, K.K. (2007). Research Methodology in Social Sciences: A

Practical Guide.Abhijit Publication, New Delhi.

Barua, S.L. (1992). Status of Women in Assam.Omson Publishers, NewDelhi.

Bhende, A. A., \&Kanitkar, T. (1996).Principles of Population Studies.

Himalaya Publishing House, Girgaon, Bombay.

Choudhury, R.D. (1985). Archaeology of the Brahmaputra Valley of

Assam (Pre-Ahom Period).Agam Kala Prakashan, Delhi.

Das, B. (1986). Socio-economic Condition of the Scheduled Caste People of Assam. Omsons Publications, New Delhi.

Datt, G., \&Mahajan , A. (2012). Indian Economy. S. Chand \& CompanyLtd., Ramnagar, New

Delhi.

Delhi University.Champion Educatio - II. King Books, NaiSarak, Delhi.

Driver, Edwin D. (1963).Differential Fertility in Central India. 1st Edition, Princeton, Princeton University Press. USA.

Dutta, Chattopadhayay P. (1995). Loops and Roots, the Conflict betweenOfficial and Traditional Family Planning in India. 1stEdition, Ashish Publishing House, New Delhi.

Dutta, Sujit K. and Ghosh, Dilip K. (2002).Empowering Rural Women. 1stPublication.Akansha Publishing House, New Delhi.

Fisher, R.A. (2006). Statistical Methods for Research Workers. Cosmo Publications, New Delhi.

Gait, Sir Ed. (2004).A History of Assam.2nd Indian Reprint.Surjeet Publications, Delhi.

Garret, H. E. (1961).Statistics in Psychology and Education. Bombay:Allied Pacific Private Limited. 